\title{
EFEKTIVITAS MODEL PEMBELAJARAN BERBASIS PROYEK DALAM PEMBELAJARAN MENULIS TEKS EKSPOSISI PESERTA DIDIK KELAS $X$ SMA NEGERI 2 SUNGGUMINASA
}

\author{
Asriani Thahir \\ Prodi PGMI FAI Universitas Islam Makassar \\ Kampus: Jalan Perintis Kemerdekaan KM. 9 No. 29 Makassar \\ Email: asrianithahir@gmail.com
}

\begin{abstract}
Abstrak:
Penelitian ini bertujuan untuk mengkaji proses dan hasil penerapan model pembelajaran berbasis proyek dalam pembelajaran menulis teks eksposisi peserta didik kelas X SMA Negeri 2 Sungguminasa. Jenis penelitian adalah penelitian eksperimen dengan desain true eksperimen. Penelitian ini dilaksanakan di SMA Negeri 2 Sungguminasa. Populasi dalam penelitian ini yaitu seluruh peserta didik kelas X yang berjumlah 239 orang. Teknik penentuan sampel yaitu proportional random sampling dan sampel yang terpilih sebanyak 70 orang. Instrumen berupa rancangan penelitian dan pedoman menulis teks eksposisi. Teknik pengumpulan data yaitu teknik tes tertulis. Data yang terkumpul kemudian dianalisis dengan menggunakan statistik deskriptif dan statistik inferensial. Hasil penelitian menunjukkan dengan Uji hipotesis menggunakan analisis inferensial jenis uji-t independen dan diperoleh nilai t sebesar 14,293 dengan derajat kebebasan 68 dan $p$ value $(2$ tailed $)=0,000$. Karena nilai $p$-value $<0,05$ atau $0,000<0,05$ atau $t$ hitung 14,293 > $\mathrm{t}$ tabel 2,04 maka hipotesis nol (H0) ditolak dan hipotesis alternatif (H1) diterima dan dapat disimpulkan bahwa penerapan model pembelajaran berbasis proyek efektif diterapkan dalam pembelajaran menulis teks eksposisi peserta didik kelas X SMA Negeri 2 Sungguminasa.
\end{abstract}

\begin{abstract}
:
This study aims to examine the process and the results of the implementation of project-based learning model in learning writing expository text of students class $X$ of SMA Negeri 2 Sungguminasa. The type of research is experimental research. The research design is true experiment. This research was conducted in SMA Negeri 2 Sungguminasa. The population in this study is all students of class $X$ which amounted to 239 people. The technique sampling used in this research was propotional random sampling and the selected sample is 70 students. Instruments used in this research were research planning exposition texts writing guidelines. Data collection techniques are written test techniques. The collected data is then analyzed by using descriptive statistics and inferential statistics. The results showed by hypothesis test using inferential analysis of independent t-test type and obtained $t$ value equals to 14,293 with degree of freedom 68 and p-value (2 tailed $)=0,000$. Since the p-value $<0,05$ or $0,000<0,05$ or $\mathrm{t}$ value $14,293>\mathrm{t}$ table 2.04, the null hypothesis (H0) is rejected and the alternative hypothesis (H1) is accepted and it can be concluded that the application of project-based learning model is effective to be applied in learning writing expository text of students class X of SMA Negeri 2 Sungguminasa.
\end{abstract}

Kata kunci:

Proyek Basic Learning, Teks Eksposisi, Hasil Belajar 
BAHASA Indonesia menjadi penghela bagi seluruh mata pelajaran pada semua jenjang pendidikan dalam Kurikulum 2013. Bahkan, jam pelajarannya pun ditambah. Komitmen ini merupakan jawaban terhadap perlunya bahasa Indonesia diajarkan dengan benar kepada peserta didik agar dapat mengekspresikan perasaan dan pengetahuannya melalui penggunaan bahasa Indonesia baku dengan baik dan benar.

Beberapa faktor pendukung pembelajaran yang perlu diperhatikan supaya proses belajar berlangsung baik adalah kesempatan untuk belajar, pengetahuan awal peserta didik, refleksi, motivasi, dan suasana yang mendukung. Oleh karena itu, dalam proses pembelajaran pada mata pelajaran bahasa Indonesia diharapkan dapat tercipta situasi pembelajaran yang memungkinkan peserta didik melakukan aktivitas secara optimal untuk mencapai tujuan keterampilan berbahasa. Keterampilan berbahasa yang dimaksud yaitu keterampilan menyimak, berbicara, membaca, dan menulis.

Berdasarkan Kurikulum 2013 keempat aspek keterampilan berbahasa tidak disebutkan secara eksplisit. Namun, sudah mencakup secara keseluruhan melalui pembelajaran berbasis teks bermuara pada keterampilan menulis. Menulis merupakan keterampilan yang harus mendapat perhatian secara sungguh-sungguh. Pengalaman selama ini menunjukkan bahwa kemampuan peserta didik dalam menulis masih rendah. Padahal kemampuan ini sangat penting. Menulis juga merupakan kemampuan puncak berbahasa seseorang yang meliputi keterampilan memilih kosakata, menggunakan struktur kalimat, menerapkan ejaan, dan tanda baca.

Menulis merupakan suatu keterampilan berbahasa yang digunakan untuk berkomunikasi secara tidak langsung atau tanpa tatap muka dengan orang lain. Menulis merupakan kegiatan yang produktif dan ekspresif. Dalam kegiatan menulis, seorang penulis harus terampil memanfaatkan grafologi, struktur bahasa, dan kosakata. Keterampilan menulis tidak akan dimiliki seseorang secara otomatis, melainkan melalui latihan dan praktik.

Pembelajaran menulis memiliki trik-trik untuk menyiasati agar kegiatan menulis ini menjadi lebih mudah. Hal ini menarik perhatian peneliti untuk meneliti upaya yang harus ditempuh untuk menarik perhatian peserta didik dalam pembelajaran menulis teks eksposisi. Menulis teks eksposisi merupakan kompetensi dasar yang terdapat dalam Kurikulum 2013. Untuk mencapai kompetensi tersebut, kegiatan belajar seharusnya lebih daripada sekadar pengajaran. Peserta didik belajar bukan hanya dari guru melainkan dari teman-teman sekelas, sekolah, dan dari sumber belajar lain.

Model pembelajaran berbasis proyek merupakan salah satu model pembelajaran yang ditawarkan dalam kurikulum 2013. Pembelajaran berbasis proyek adalah sebuah model pembelajaran yang inovatif dan lebih menekankan pada belajar kontekstual melalui kegiatan-kegiatan yang kompleks (Wena, 2011: 145). Kegunaan model ini memberi kesempatan pada peserta didik bekerja secara otonom dalam mengonstruksi pengetahuan mereka sendiri, dan mencapai puncaknya untuk menghasilkan produk nyata.

Pelaksanaan model pembelajaran berbasis proyek dalam menulis teks eksposisi meliputi beberapa langkah-langkah, yaitu: (1) essensial question, meliputi peserta didik 
mengamati fenomena peristiwa yang terjadi di lingkungan untuk menetukan tema dalam menulis teks ekposisi dan mengidentifikasi stuktur, kaidah/ciri kebahasaan dalam teks eksposisi; (2) designing project, meliputi peserta didik menyusun perencanaan untuk menginvestigasi atau mencari sumber-sumber yang terkait dengan tema yang telah ditentukan; (3) creating schedule, meliputi peserta didik menentukan tempat dan waktu untuk menginvestigasi atau mencari sumber yang terkait dengan tema; (4) monitoring the progress, meliputi peserta didik mengumpulkan sumber-sumber yang mereka dapatkan sesuai dengan tema; (5) asses the autcome, meliputi peserta didik memilih sumber-sumber yang bisa dikembangkan menjadi sebuah teks eksposisi kemudian membuat pola pengembangan dan memberikan rincian atau gagasan pokok; dan (6) evaluate the exsperiment, mengembangkan gagasan pokok dan gagasan pendukung menjadi karangan yang utuh dan padu. Selanjutnya, hasil menulis teks eksposisi dipresentasikan. Dari uraian di atas dapat diasumsikan jika model pembelajaran berbasis proyek efektif digunakan dalam menulis teks eksposisi.

\section{KAJIAN PUSTAKA}

\section{Pembelajaran Berbasis Proyek}

Model pembelajaran berbasis proyek adalah model pembelajaran yang memberikan kesempatan kepada guru untuk mengelola pembelajaran di kelas dengan melibatkan kerja proyek. (Thomas dalam Wena, 2011: 144). Pembelajaran Berbasis Proyek merupakan metode belajar yang menggunakan masalah sebagai langkah awal dalam mengumpulkan dan mengintegrasikan pengetahuan baru berdasarkan pengalamannya dalam beraktivitas secara nyata. Pembelajaran Berbasis Proyek dirancang untuk digunakan pada permasalahan kompleks yang diperlukan peserta didik dalam melakukan insvestigasi dan memahaminya. Melalui model pembelajaran berbasis proyek, proses inquiry dimulai dengan memunculkan pertanyaan penuntun (a guiding question) dan membimbing peserta didik dalam sebuah proyek kolaboratif yang mengintegrasikan berbagai subjek (materi) dalam kurikulum.

Menurut Badan Pengembangan Sumber Daya Manusia Pendidikan dan Kebudayaan dan Penjaminan Mutu Kebudayaan (2013), Pembelajaran Berbasis Proyek (Project Based Learning) adalah metode pembelajaran yang menggunakan proyek sebagai media. Peserta didik melakukan eksplorasi, penilaian, interpretasi, sintesis, dan informasi untuk menghasilkan berbagai bentuk hasil belajar. Langkah utama Pembelajaran Berbasis Proyek adalah: (1) Penentuan pertanyaan mendasar (essential question), (2) Menyusun perecanaan proyek (designing project plan), (3) Menyusun jadwal (creating schedule), (4) Monitoring, (4) Menguji hasil (assess the outcome), dan (5) Evaluasi pengalaman (evaluate the experiment).

Pelaksanaan model pembelajaran berbasis proyek dalam menulis teks eksposisi meliputi beberapa langkah-langkah, yaitu: (1) essensial question, meliputi peserta didik mengamati fenomena yang tejadi di lingkungan untuk menetukan tema dalam menulis teks ekposisi dan mengidentifikasi stuktur, kaidah/ciri kebahasaan dalam teks eksposisi; (2) designing project, meliputi peserta didik menyusun perencanaan untuk 
menginvestigasi atau mencari sumber-sumber yang terkait dengan tema yang telah ditentukan; (3) creating schedule, meliputi peserta didik menentukan tempat dan waktu untuk menginvestigasi atau mencari sumber yang terkait dengan tema; (4) monitoring the progress, meliputi peserta didik mengumpulkan sumber-sumber yang mereka dapatkan sesuai dengan tema; (5) asses the autcome, meliputi peserta didik memilih sumber-sumber yang bisa dikembangkan menjadi sebuah teks eksposisi kemudian membuat pola pengembangan dan memberikan rincian atau gagasan pokok; dan (6) evaluate the exsperiment, mengembangkan gagasan pokok dan gagasan pendukung menjadi karangan yang utuh dan padu. Selanjutnya, hasil menulis teks eksposisi dipresentasikan.

\section{Pembelajaran Menulis Teks Eksposisi}

Menulis ialah menurunkan atau melukiskan lambang-lambang grafik yang menggambarkan suatu bahasa yang dipahami oleh seseorang sehingga orang lain dapat membaca lambang-lambang grafik tersebut kalau mereka memahami bahasa dan gambaran grafik itu. (Tarigan, 2008: 21).

Selanjutnya menurut Gie (2002: 3), menulis diistilahkan mengarang, yaitu segenap rangkaian kegiatan seseorang untuk mengungkapkan gagasan dan menyampaikannya melalui bahasa tulis kepada masyarakat pembaca untuk dipahami. Dalam kehidupan modern ini, jelas bahwa keterampilan menulis sangat dibutuhkan. Menulis dipergunakan sesesorang untuk mencatat atau merekam, meyakinkan, melaporkan atau memberitahukan, dan memengaruhi orang lain. Maksud dan tujuan seperti itu hanya dapat dicapai dengan baik oleh orang-orang yang dapat menyusun pikirannya dan mengutarakannya dengan jelas. Kejelasan ini bergantung pada pikiran, organisasi, dan pemakaian kata-kata yang jelas dan baik.

Dari beberapa pendapat di atas, dapat disimpulkan bahwa menulis dalam hubungannya dengan penelitian ini adalah suatu kegiatan seseorang dalam mengungkapkan ide, gagasan atau buah pikiran melalui tulisan. Buah pikiran tersebut dapat berupa pendapat, pengetahuan, pengalaman, keinginan, atau pun perasaan seseorang. Menulis tidak hanya mengungkapkan gagasan melalui bahasa tulis melalui media bahasa tulis saja, tetapi meramu tulisan tersebut agar dapat dipahami pembaca.

Menurut Tarigan (2008: 7) ciri-ciri tulisan yang baik adalah (1) jelas, pembaca dapat membaca teks dengan cara tetap dan pembaca tidak boleh bingung dan harus mampu menangkap maknanya yang dikatakan oleh penulis; (2) kesatuan organisasi, pembaca dapat mengikuti dengan mudah karena bagian-bagiannya saling behubungan; (3) ekonomis, penulis tidak akan menggunkan kata atau bahasa yang berlebihan sehingga waktu yang digunakan pembaca tidak terbuang percuma; dan (4) pemakaian bahasa dapat diterima, penulis menggunakan bahasa yang baik dan benar karena bahasa yang dipakai masyarakat kebanyakan terutama berpendidikan lebih mengutamakan bahasa formal sehingga mudah diterima.

Tujuan menulis adalah untuk mengekspresikan perasaan, member informasi, memengaruhi pembaca, meyakinkan, dan memberi hiburan. Tujuan menulis juga da- 
pat memberikan arahan, menjelaskan sesuatu, menceritakan kejadian, memberikan informasi tentang sesuatu yang berlangsung di suatu tempat pada suatu waktu, meringkas atau membuat rangkuman suatu tulisan sehingga menjadi lebih singkat.

Dalam kurikulum 2013, teks tidak diartikan sebagai bentuk bahasa tulis. Teks adalah ungkapan pikiran manusia yang lengkap yang di dalamnya ada situasi dan konteksnya (Mahsun: 2013). Teks dibentuk oleh konteks situasi penggunaan bahasa yang di dalamnya ada register atau ragam bahasa yang melatarbelakangi lahirnya teks tersebut. Maryanto (2013) juga menyatakan bahwa yang dimaksud teks dalam Kurikulum 2013 berbentuk tulisan, lisan, dan bahkan multi modal seperti gambar.

Teks merupakan sistem komunikasi yang selalu diproduksi disusun sebagai unit kohesif. Sebuah teks yang padu berasal dari tindakan komunikasi lisan dan tulisan (Knaap, 2005: 29). Dalam Kamus Besar Bahasa Indonesia (2002: 1159) teks adalah naskah yang berupa kata-kata asli dari pengarang, kutipan dari kitab suci untuk pangkal ajaran atau alasan, bahan tertulis untuk dasar memberikan pelajaran, berpidato, dan sebagainya. Teks adalah seperangkat unit bahasa, baik lisan maupun tulisan, dengan ukuran tertentu, makna tertentu, serta tujuan tertentu. Teks bisa berupa kata, kalimat, atau wacana, yang memiliki karakteristik tertentu secara konvensional diterima, secara kogniktif dipahami, yang kemudian karakteristik teks itu sendiri disebut tekstur (Zinurrahman, 2011: 128).

Dalam kepentingan menulis, ada beberapa bagian-bagian teks yaitu kohesi dan koherensi. Kohesi adalah hubungan internal dalam teks, namun lebih kepada bentuk dan tidak secara langsung kepada makna (Zainurrahman, 2011: 129). Strazny (Zainurrahman, 2011: 139) memberikan penjelasan bagaimana koherensi dan kohesi menjadi berbeda. Jika kohesi, menurutnya, berhubungan dengan struktur permukaan teks, maka koherensi berhubungan dengan konsep-konsep yang mendasari makna dari teks. Jika kohesi berhubungan dengan unit-unit di dalam teks, maka koherensi berhubungan dengan hubungan-hubungan keseluruhan dalam teks.

Kata eksposisi berasal dari kata bahasa Inggris expotition sebenarnya berasal dari bahasa Latin yang berarti 'membuka atau memulai'. Memang teks eksposisi merupakan teks yang bertujuan untuk memberi tahu, mengupas, menguraikan, atau menerangkan sesuatu. Dalam teks eksposisi, masalah yang dikomunikasikan terutama adalah pemberitahuan atau informasi (Finoza, 2001: 204).

Lain halnya dengan Alwasilah (2005: 111) yang menyatakan eksposisi adalah tulisan yang tujuan utamanya mengklarifikasi, menjelaskan, mendidik, atau mengevaluasi sebuah persoalan. Penulis berniat untuk memberi petunjuk kepada pembaca. Eksposisi mengandalkan strategi pengembangan alinea seperti lewat pemberian contoh, proses, sebab-akibat, klasifikasi, definisi, analisis, komparasi, dan kontras.

Berdasarkan beberapa pendapat di atas maka dapat disimpulkan bahwa eksposisi adalah suatu bentuk tulisan atau retorika untuk menerangkan dan menguraikan suatu pokok pikiran yang dapat memperluas pandangan atau pengetahuan pembaca. Eksposisi juga mengandalkan strategi pengembangan alinea seperti lewat pemberian contoh, proses, sebab-akibat, klasifikasi, definisi, analisis, komparasi, dan kontras. 


\section{METODOLOGI PENELITIAN}

Jenis penelitian yang digunakan adalah true eksperiment atau eksperimen murni. Dalam penelitian ini terdapat dua jenis variabel, yaitu: variabel bebas $(X)$ ialah model pembelajaran, dan variabel terikat $(\mathrm{Y})$ ialah pembelajaran menulis teks eksposisi dengan penggunaan model pembelajaran berbasis proyek.

Populasi penelitian ini adalah keseluruhan peserta didik Kelas X SMA Negeri 2 Sungguminasa yang berjumlah 239 peserta didik. Pengambilan sampel dalam penelitian ini dilakukan dengan teknik propotional random sampling. Dalam penelitian ini, sampel diambil dari tiap kelas berjumlah 70 peserta didik.

Instrumen yang terdiri atas dua, yaitu: rancangan penelitian dan pedoman menulis teks eksposisi. Teknik pengupulan data dalam penelitian ini yaitu teknik tes. Teknik tes yaitu tes dengan bentuk soal esai dan menulis teks eksposisi guna memeroleh tingkat pengetahuan dan kemampuan peserta didik dalam menulis teks eksposisi. Dalam penelitian ini, data yang terkumpul akan dianalisis dengan menggunakan teknik statistik deskriptif dan analisis statistika inferensial.

\section{HASIL PENELITIAN DAN PEMBAHASAN}

\section{Proses dan Hasil Penerapan Model Pembelajaran Berbasis Proyek dalam Pembe- lajaran Menulis Teks Eksposisi}

Hasil observasi terhadap aktivitas peserta didik pada saat penerapan model pembelajaran berbasis proyek dalam menulis teks eksposisi pada pertemuan pertama, kedua, dan ketiga sudah terdapat peserta didik yang menunjukkan sikap religius, disiplin, bertanggung jawab, jujur, dan santun.

Kegiatan pembelajaran kelas eksperimen pada pertemuan pertama, kedua, dan ketiga mulai dari kegiatan peserta didik berdoa sebelum memulai proses pembelajaran yang menunjukkan sikap religius tidak terdapat peserta didik yang tidak aktif. Sikap disiplin ditunjukkan dengan mempersiapkan perlengkapan pembelajaran. Hanya terdapat 3 orang $(8,6 \%)$ yang tidak aktif pada pertemuan pertama, pertemuan kedua hanya 2 orang $(57,2)$ yang tidak aktif, dan pertemuan ketiga hanya 3 orang $(8,6 \%)$ yang tidak aktif. Kegiatan peserta didik bertanya dan menyampaikan mendapat dengan santun, mengerjakan tugas dengan jujur dan tanggung jawab, dan melaksanakan langkah-langkah kegiatan pembelajaran berbasis proyek dengan proaktif didominasi oleh peserta didik yang aktif.

Aktivitas peserta didik pada setiap kegiatan proses pembelajaran sudah menunjukkan sikap religius, santun, disiplin, dan bertanggung jawab. Hal tersebut sudah sejalan dengan Kurikulum 2013 membagi kompetensi sikap menjadi dua, yaitu: sikap spiritual yang terkait dengan pembentukan peserta didik yang beriman dan bertakwa, dan sikap sosial yang terkait dengan pembentukan peserta didik yang berakhlak mulia dan bertanggung jawab. Sikap spiritual sebagai perwujudan dari menguatnya interaksi vertikal dengan Tuhan Yang Maha Esa, sedangkan sikap sosial sebagai perwujudan eksistensi kesadaran dalam upaya mewujudkan harmoni kehidupan (Kemendikbud: 2013). 
Kegiatan peserta didik yang menunjukkan sikap proaktif dan bertanggung jawab berpengaruh positif terhadap kemampuan menulis teks eksposisi peserta didik. Hal tersebut ditunjukkan berdasarkan hasil analisis deskriptif yang memperlihatkan bahwa hasil belajar peserta didik kelas eksperimen dengan penerapan model pembelajaran berbasis proyek diperoleh skor rata-rata 77,64 dari skor ideal 100 dengan jumlah peserta didik 35, dari tes awal yang hanya mencapai nilai rata-rata 50,11 perolehan nilai tertinggi 59,84. Setelah diadakan perlakuan dengan penerapan model pembelajaran berbasis proyek, perolehan nilai tetinggi yaitu 92,50 yang diperoleh 1 orang peserta didik (2,9\%), sedangkan nilai terendah yaitu 56,92 . Hasil perolehan setiap aspek penilaian eksposisi peserta didik diperoleh nilai rata-rata pretes 64,41 dan postes 79,66 . Hal tersebut menunjukkan adanya perbedaan yang signifikan dari hasil pretes ke postes.

Pembelajaran menulis teks eksposisi dengan menggunakan model pembelajaran berbasis proyek dapat meningkatkan kemampuan hasil belajar peserta didik. Hal ini dapat terlihat dari perubahan yang sangat signifikan pada hasil belajar peserta didik dalam menulis karangan eksposisi dalam proses pembelajaran. Hal ini disebabkan tulisan peserta didik sudah mengetahui berbagai unsur kebahasaan dan unsur di luar bahasa itu sendiri yang akan menjadi isi tulisan. Hal ini sejalan dengan pendapat Iskandarwasid dan Sunendar (2008: 248) yang menyatakan bahwa unsur bahasa maupun unsur isi harus terjalin sedemikian rupa sehingga menghasilkan tulisan yang runtut dan padu.

Penerapan model pembelajaran berbasis proyek menunjukkan pengaruh positif terhadap perolehan nilai peserta didik. Melalui model pembelajaran berbasis proyek peserta didik dapat membangun pengetahuannya sesuai perencanaan dengan melakukan investigasi terhadap pengalaman dunia nyata. Pelaksanaan proyek dilakukan secara kolaboratif, inovatif, dan unik, yang berfokus pada pemecahan masalah yang berhubungan dengan kehidupan peserta didik. Hal tersebut mengakibatkan motivasi belajar peserta didik sangat tinggi. Hal tersebut sejalan dengan pendapat yang dikemukakan oleh Grant (2008) bahwa aplikasi model pembelajaran berbasis proyek ini mempunyai beberapa alasan, yaitu: (1) menawarkan potensi produksi dan tindakan pengetahuan kolektif di dalam proyek sosial, (2) pengembangan pengetahuan yang melibatkan pengembangan pemikiran, dan (3) proses kerja kelompok yang saling mendukung dapat membuka berbagai peluang untuk kreativitas, karena peserta didik mengadakan percobaan dengan penafsiran berpikir dan data berbeda untuk menyelesaikan permasalahan dalam proyek mereka yang dapat diterapkan untuk mengembangkan pembentukan masyarakat praktek.

Pembelajaran berbasis proyek dalam menulis teks eksposisi sebagai salah satu wahana yang memaksimalkan aktivitas peserta didik dalam meningkatkan motivasi belajar dan kinerja ilmiah peserta didik dan membantu peserta didik untuk mengembangkan keterampilan menulis. Peserta didik mengetahui bahwa mereka adalah mitra penuh dalam lingkungan pelajaran ini dan bertanggung jawab dalam proses pelajaran. Selain itu, pembelajaran berbasis proyek juga dapat meningkatkan keyakinan 
diri para peserta didik, motivasi untuk belajar, kemampuan kreatif, dan mengagumi diri sendiri. Hal tersebut sejalan dengan uraian yang diungkapkan oleh (Sampurno: 2009) yang menyatakan bahwa pembelajaran berbasis proyek memiliki potensi yang amat besar untuk membuat pengalaman belajar yang lebih menarik dan bermakna untuk pebelajar serta dapat meningkatkan kinerja ilmiah siswa dalam pembelajaran, sedangkan guru hanya berperan sebagai fasilitator dan mediator. Keuntungan-keuntungan pembelajaran berbasis proyek, yaitu: (1) meningkatkan motivasi belajar siswa, (2) meningkatkan kemampuan pemecahan masalah, (3) meningkatkan kolaborasi. Pentingnya kerja kelompok dalam proyek menyebabkan siswa mampu mengembangkan dan mempraktikkan keterampilan komunikasi dan kinerja ilmiah siswa, (4) meningkatkan keterampilan mengelola sumber yaitu bertanggung jawab untuk menyelesaikan tugas yang kompleks.

Berdasarkan sikap yang ditunjukkan peserta didik pada saat proses pembelajaran dan hasil kemampuan menulis teks ekposisi sudah menunjukkan kesimbangan antara kompetensi sikap, pengetahuan, dan keterampilan. Hal tersebut sejalan dengan Kurikulum 2013 yang menekankan keseimbangan tiga ranah kompetensi, yaitu ranah sikap, ranah pengetahuan, dan ranah keterampilan. Kemampuan berbahasa peserta didik diwujudkan melalui pembelajaran berkelanjutan dimulai dengan meningkatkan pengetahuan, keterampilan menyajikan, baik secara spontan maupun terencana dan bermuara pada pembentukan sikap (Kementerian Pendidikan dan Kebudayaan RI: 2013).

Analisis inferensial berikut adalah analisis keefektifan model pembelajaran berbasis proyek dalam menulis teks eksposisi peserta didik kelas X SMA Negeri 2 Sungguminasa. Analisis tersebut diketahui berdasarka hasil analisis data tes kelas eksperimen dan kelas kontrol. Analisis statistik inferensial digunakan untuk menguji hipotesis. Hipotesis ini disusun berdasarkan dugaan awal atau jawaban sementara berdasarkan teori-teori yang telah dikemukakan sebelumnya. Selanjutnya, untuk memastikan bahwa jawaban sementara atau hipotesis tersebut terbukti atau tidak, dilakukan teknik analisis uji $\mathrm{t}$ yang bertujuan untuk membuktikan apakah hipotesis alternatif (H1) sesuai dengan hasil penelitian atau hipotesis nol (H0) yang sesuai dengan hasil penelitian. Sebelum dilakukan uji-t perbedaan tersebut, terlebih dahulu dilakukan uji prasyarat. Uji prasyarat yang dimaksud adalah uji normalitas dan uji homogenitas. Hal ini dilakukan untuk mengetahui apakah data yang diperoleh dari hasil penelitian berdistribusi normal dan homogen.

\section{Uji Normalitas}

Pengujian normalitas untuk mengetahui data tentang hasil belajar peserta didik pada tiap-tiap kelompok perlakuan berasal dari populasi yang berdistribusi normal atau tidak. Hasil perhitungan dengan menggunakan program SPSS 19 disajikan dalam bentuk tabel berikut ini. 
Tabel 1. Uji Normalitas Kolmogrov-Smirnov untuk Data Pretes dan Postes Kelas Eksperimen

\begin{tabular}{|ll|l|l|}
\hline & & Pre & Post \\
\hline $\mathrm{N}$ & & 35 & 35 \\
Normal Parametersa,b & Mean & 50.5923 & 77.6420 \\
& Std. Deviation & 6.92824 & 7.48195 \\
Most Extreme Differences & Absolute & .188 & .129 \\
& Positive & .096 & .110 \\
& Negative & -.188 & -.129 \\
Kolmogorov-Smirnov Z & & 1.111 & .766 \\
Asymp. Sig. (2-tailed) & & .169 & .601 \\
\hline
\end{tabular}

A. Test distribution is normal.

B. Calculated from data

Taraf signifikansi pretes kelas eksperimen yang diberi simbol $p=0,169$ ini berarti signifikansi $\mathrm{p}>\mathrm{a}=0,05$ berarti data yang diambil mengikuti distribusi normal. Taraf signifikansi postes kelas eksperimen yang diberi simbol $p=0,601$ ini berarti signifikansi $p>a=0,05$ berarti data yang diambil mengikuti distribusi normal.

Tabel 2. Uji normalitas kolmogrov-smirnov untuk data pretes dan postes kelas kontrol

\begin{tabular}{|ll|l|l|}
\hline & & Pre & Post \\
\hline $\mathrm{N}$ & & 35 & 35 \\
Normal parametersa, $\mathrm{b}$ & Mean & 42.3083 & 50.7386 \\
& Std. Deviation & 4.27284 & 8.24734 \\
Most extreme differences & Absolute & .226 & .251 \\
& Positive & .226 & .251 \\
& Negative & -.187 & -.174 \\
Kolmogorov-smirnov z & & 1.339 & 1.484 \\
Asymp. Sig. (2-tailed) & & .055 & .024 \\
\hline
\end{tabular}

A. Test distribution is normal.

B. Calculated from data.

Taraf signifikansi pretes kelas kontrol yang diberi simbol $p=0,055$ ini berarti signifikansi $\mathrm{p}>\mathrm{\alpha}=0,05$ berarti data yang diambil mengikuti distribusi normal. Taraf signifikansi postes kelas kontrol yang diberi simbol $p=0,24$ ini berarti signifikansi $p>$ $\alpha=0,05$ berarti data yang diambil mengikuti distribusi normal.

\section{Uji Homogenitas}

Pengujian homogenitasnya digunakan test of homogeneity of variance yang bertujuan untuk mengetahui apakah variansi kedua data homogen. Data hasil belajar yang diperoleh dikatakan homogen jika p-value $>\alpha=0,05$. Hasil perhitungan dengan menggunakan program spss 19 disajikan dalam bentuk tabel berikut ini. 
Tabel 3. Uji homogenitas untuk data postes dan pretes kelas eksperimen

\begin{tabular}{|l|l|l|l|l|}
\hline & Levene statistic & Df1 & Df2 & Sig. \\
\hline Pre & .915 & 1 & 33 & .346 \\
Post & 1.494 & 1 & 33 & .230 \\
\hline
\end{tabular}

Taraf signifikansi pretes kelas eksperimen yang diberi simbol $p=0,346$ ini berarti signifikansi $p>a=0,05$ berarti variansi data yang diambil homogen. Taraf signifikansi postes kelas eksperimen yang diberi simbol $p=0,230$ ini berarti signifikansi $p>$ $\alpha=0,05$ berarti variansi data yang diambil homogen.

Tabel 4. Uji homogenitas untuk data postes dan pretes kelas kontrol

\begin{tabular}{|l|l|l|l|l|}
\hline & Levene statistic & Df1 & Df2 & Sig. \\
\hline Pre & 2.242 & 1 & 33 & .144 \\
Post & .094 & 1 & 33 & .762 \\
\hline
\end{tabular}

Taraf signifikansi pretes kelas eksperimen yang diberi simbol $p=0,144$ ini berarti signifikansi $p>a=0,05$ berarti variansi data yang diambil homogen. Taraf signifikansi postes kelas eksperimen yang diberi simbol $p=0,762$ ini berarti signifikansi $p>$ $a=0,05$ berarti variansi data yang diambil homogen.

\section{Uji- $t$}

Uji hipotesis yang digunakan adalah teknik analisis uji $t$ independen (independent sample $t$ test) setelah sebelumnya dilakukan uji prasyarat analisis yaitu, uji normalitas dan uji homogenitas, dan diperoleh hasil bahwa data tersebut normal dan homogen. Nilai yang dijadikan perhitungan pada uji-t independen adalah nilai akhir siswa setelah diadakan postes pada kelas eksperimen dan kelas kontrol. Hasil analisis statistik independent sample $t$ test diperoleh hasil sebagai berikut.

Tabel 5. Statistik Uji t-test

\begin{tabular}{|c|c|c|c|c|c|c|c|c|c|c|}
\hline & \multicolumn{2}{|c|}{$\begin{array}{l}\text { Levene's } \\
\text { Test for } \\
\text { Equality } \\
\text { of } \\
\text { Varianc } \\
\text { es }\end{array}$} & \multicolumn{7}{|c|}{ t-test for Equality of Means } \\
\hline & & \multirow[b]{2}{*}{ F } & \multirow[t]{2}{*}{ Sig } & \multirow[b]{2}{*}{$\mathrm{T}$} & \multirow[b]{2}{*}{ Df } & \multirow{2}{*}{$\begin{array}{l}\text { Sig. } \\
(2- \\
\text { tailed } \\
)\end{array}$} & \multirow{2}{*}{$\begin{array}{l}\text { Mean } \\
\text { Differenc } \\
\text { e }\end{array}$} & \multirow{2}{*}{$\begin{array}{l}\text { Std. } \\
\text { Error } \\
\text { Differenc } \\
\text { e }\end{array}$} & \multicolumn{2}{|c|}{$\begin{array}{l}95 \% \text { Confidence } \\
\text { Interval of the } \\
\text { Difference }\end{array}$} \\
\hline & & & & & & & & & Lower & Upper \\
\hline Post & $\begin{array}{l}\text { Equal } \\
\text { variances } \\
\text { assumed }\end{array}$ & .392 & .533 & $\begin{array}{l}- \\
14.293\end{array}$ & 68 & .000 & -26.90343 & 1.88223 & $\begin{array}{l}- \\
30.65937\end{array}$ & $\begin{array}{l}- \\
23.14749\end{array}$ \\
\hline
\end{tabular}


Tabel 5. Statistik Uji t-test

\begin{tabular}{|c|c|c|c|c|c|c|c|c|c|c|}
\hline & \multicolumn{2}{|c|}{$\begin{array}{l}\text { Levene's } \\
\text { Test for } \\
\text { Equality } \\
\text { of } \\
\text { Varianc } \\
\text { es }\end{array}$} & \multicolumn{7}{|c|}{ t-test for Equality of Means } \\
\hline & & \multirow[b]{2}{*}{$\mathrm{F}$} & \multirow[t]{2}{*}{ Sig } & \multirow[b]{2}{*}{$\mathrm{T}$} & \multirow[b]{2}{*}{ Df } & \multirow{2}{*}{$\begin{array}{l}\text { Sig. } \\
(2- \\
\text { tailed } \\
)\end{array}$} & \multirow{2}{*}{$\begin{array}{l}\text { Mean } \\
\text { Differenc } \\
\text { e }\end{array}$} & \multirow{2}{*}{$\begin{array}{l}\text { Std. } \\
\text { Error } \\
\text { Differenc } \\
\text { e }\end{array}$} & \multicolumn{2}{|c|}{$\begin{array}{l}95 \% \text { Confidence } \\
\text { Interval of the } \\
\text { Difference }\end{array}$} \\
\hline & & & & & & & & & Lower & Upper \\
\hline \multirow[t]{2}{*}{ Post } & $\begin{array}{l}\text { Equal } \\
\text { variances } \\
\text { assumed }\end{array}$ & .392 & .533 & $\begin{array}{l}- \\
14.293\end{array}$ & 68 & .000 & -26.90343 & 1.88223 & $\begin{array}{l}- \\
30.65937\end{array}$ & $\begin{array}{l}- \\
23.14749\end{array}$ \\
\hline & $\begin{array}{l}\text { Equal } \\
\text { varianc } \\
\text { es not } \\
\text { assume } \\
\text { d }\end{array}$ & & & $\begin{array}{l}- \\
14.29 \\
3\end{array}$ & $\begin{array}{l}67.36 \\
5\end{array}$ & .000 & -26.90343 & 1.88223 & $\begin{array}{l}- \\
30.6600 \\
1\end{array}$ & $\begin{array}{l}- \\
23.1468 \\
5\end{array}$ \\
\hline
\end{tabular}

Hasil analisis statistik inferensial menunjukkan bahwa koefesien beda antara nilai kemampuan menulis teks eksposisi dengan penerapan pembelajaran berbasis proyek dengan nilai keterampilan menulis teks eksposisi dengan penerapan pembelajaran langsung pada peserta didik kelas X SMA Negeri 2 Sungguminasa yang dijadikan sebagai subjek penelitian. Koefesien beda antara nilai kemampuan menulis teks eksposisi berbasis proyek dengan pembelajaran langsung pada peserta didik kelas $X$ SMA Negeri 2 Sungguminasa yang diperoleh nilai t sebesar 14,293dengan derajat kebebasan 68 dan p-value ( 2 tailed) $=0,000$. Karena nilai p-value $<0,05$ atau 0,000 $<0,05$ maka hipotesis nol (H0) ditolak dan hipotesis alternatif (H1) diterima.

Berdasar pada hasil analisis uji hipotesis tersebut, maka dapat disimpulkan bahwa terdapat perbedaan secara signifikan antara kemampuan menulis teks eksposisi dengan penerapan model pembelajaran berbasis proyek pada peserta didik kelas $X$ SMA Negeri 2 Sungguminasa dengan kemampuan menulis teks eksposisi dengan penerapan model pembelajaran langsung pada peserta didik kelas X SMA Negeri 2 Sungguminasa.

\section{Keefektifan Model Pembelajaran Berbasis Proyek dalam Pembelajaran Menulis Teks Eksposisi}

Berdasarkan uraian hasil perhitungan statistik dari proses pembelajaran langsung pada kelas kontrol dan penerapan model pembelajaran berbasis proyek menunjukkan perbedaan yang sangat signifikan. Hasil belajar peserta didik kelas X SMA Negeri 2 Sungguminasa yang mengikuti pembelajaran dengan penerapan model pembe- 
lajaran berbasis proyek lebih tinggi daripada hasil belajar siswa yang mengikuti pembelajaran dengan penerapan pembelajaran langsung. Hal tersebut berdasarkan hasil analisis statistik yang menyatakan bahwa nilai t sebesar 14,293 dengan derajat kebebasan 68 dan p-value $(2$ tailed $)=0,000$. Karena nilai $p$-value $<0,05$ atau 0,000 $<0,05$ maka hipotesis nol (H0) ditolak dan hipotesis alternatif (H1) diterima. Dengan demikian, dapat dikatakan model pembelajaran berbasis proyek efektif diterapkan dalam menulis teks eksposisi.

Dalam penelitian ini telah dilaksanakan proses menulis teks eksposisi dengan model pembelajaran bebasis proyek, peserta didik diarahkan untuk mengungkapkan pengetahuan mereka mengenai teks eksposisi. Selanjutnya, siswa ditugaskan untuk mencari sumber-sumber yang terkait dengan tema. Hal ini bertujuan supaya peserta didik memeroleh informasi tambahan yang nantinya dapat digunakan sebagai media untuk memeroleh ide. Hal ini sejalan dengan pendapat Cleary dan Linn (dalam Rahaor, 2006: 34) bahwa temuan yang paling mengejutkan dari penelitian mutakhir tentang tulisan adalah adanya korelasi antara membaca luas yang baik dengan menulis yang baik. Untuk itu, agar siswa mampu menulis karangan eksposisi dengan baik maka siswa perlu membaca sebuah informasi. Salah satu sumber informasi yaitu dari koran, bahkan dari internet.

Penerapan model pembelajaran berbasis proyek efektif dalam menulis teks eksposisi disebabkan peserta didik lebih kolaboratif dan terlibat secara aktif menyelesaikan proyek-proyek secara mandiri dan bekerja sama dalam tim dan mengintegrasikan masalah-masalah yang nyata dan praktis. Hal tersebut sejalan dengan pendapat yang dikemukakan Wena (2011: 145) bahwa model pembelajaran berbasis proyek memiliki karakteristik, yaitu (1) peserta didik membuat keputusan dan membuat kerangka kerja; (2) terdapat masalah yang pemecahannya tidak ditentukan sebelumnya; (3) peserta didik merancang proses untuk mencapai hasil; (4) peserta didik bertanggung jawab untuk mendapatkan dan mengelola informasi yang dikumpulkan; (5) peserta didik melakukan evaluasi secara berkelanjutan; (6) peserta didik secara teratur melihat kembali apa yang meraka kerjakan; (7) hasil akhir berupa produk dan dievaluasi kualitasnya; (8) kelas memiliki atmosfir yang memberikan toleransi kesalahan dan perubahan.

Hasil penelitian ini sesuai dengan penelitian yang pernah dilakukan oleh Juliana tahun 2013 dengan judul penelitian "Keefektifan Model Pembelajaran Berbasis Proyek terhadap Kemampuan Memahami Novel Siswa Kelas VIII SMP Negeri 2 Kabupaten Bulukumba". Hasil analisis statistik inferensial menunjukkan bahwa penerapan model pembelajaran berbasis proyek efektif dalam meningkatkan kemampuan memahami novel siswa kelas VIII SMP Negeri 2 Kabupaten Bulukumba. Penelitian ini merupakan penelitian eksperimen yang dilakukan pada tahun 2013 di Makassar. Penelitian ini mengkaji pengaruh model pembelajaran berbasis proyek pada hasil belajar siswa memahami novel, sedangkan untuk penelitian kali ini mengkaji pengaruh model pembelajaran berbasis proyek pada hasil belajar peserta didik menulis teks eksposisi. Berdasarkan perbandingan tersebut, hasil penelitian ini sekaligus menun- 
jukkan bahwa efektivitas model pembelajaran berbasis proyek tidak hanya pada pembelajaran memahami novel tetapi juga berlaku pada pembelajaran menulis teks eksposisi.

\section{SIMPULAN}

Proses penerapan pembelajaran langsung dalam menulis teks eksposisi pada kelas kontrol melalui pengamatan aktivitas peserta didik pada setiap kegiatan proses pembelajaran sudah menunjukkan sikap religius, santun, disiplin, jujur, proaktif, dan bertanggung jawab. Akan tetapi, dalam kegiatan proses pembelajaran lebih dominan peserta didik yang tidak aktif. Sikap proaktif dan bertanggung jawab yang ditunjukkan peserta didik lebih dominan yang tidak aktif mengakibatkan hasil kemampuan menulis teks eksposisi tidak menunjukkan pengaruh positif dan perubahan yang signifikan dari pretes ke postes. Hal tersebut ditunjukkan berdasarkan hasil analisis deskriptif nilai kemampuan yaitu hasil pretes yang hanya mencapai nilai rata-rata 42,3, perolehan nilai tertinggi 48,4 . Setelah diadakan pembelajaran langsung dengan metode ceramah, diperoleh nilai rata-rata 50,72 dari skor ideal 100 dengan jumlah peserta didik 35, dari perolehan nilai tetinggi yaitu mencapai 67,92 yang diperoleh 1 orang peserta didik $(2,9 \%)$, sedangkan nilai terendah yaitu 35,75 . Hasil perolehan setiap aspek penilaian eksposisi peserta didik diperoleh nilai rata-rata pretes 60,04 dan postes 59,76 . Hal tersebut menunjukkan tingkat kemampuan peserta didik menulis teks eksposisi masih kurang.

Proses penerapan model pembelajaran berbasis proyek pada kelas eksperimen melalui pengamatan aktivitas peserta didik pada setiap kegiatan proses pembelajaran sudah menunjukkan sikap religius, santun, proaktif, disiplin, jujur, dan bertanggung jawab. Kegiatan peserta didik yang menunjukkan sikap proaktif dan bertanggung jawab yang lebih dominan aktif berpengaruh positif terhadap kemampuan menulis teks eksposisi peserta didik. Hal tersebut ditunjukkan berdasarkan hasil analisis deskriptif nilai kemapuan, yaitu hasil pretes hanya mencapai nilai rata-rata 50,11, perolehan nilai tertinggi 59,84. Setelah diadakan perlakuan dengan penerapan model pembelajaran berbasis proyek, diperoleh nilai rata-rata 77,64 dari skor ideal 100 dengan jumlah peserta didik 35 perolehan nilai tetinggi yaitu mencapai 92,50 yang diperoleh 1 orang peserta didik (2,9\%), sedangkan nilai terendah yaitu 56,92. Hasil perolehan setiap aspek penilaian eksposisi peserta didik diperoleh nilai rata-rata pretes 64,41 dan postes 79,66 . Hal tersebut menunjukkan adanya perbedaan yang signifikan dari hasil pretes ke postes.

Terdapat perbedaan yang signifikan antara pembelajaran menulis teks eksposisi berbasis proyek dengan pembelajaran keterampilan menulis teks eksposisi dengan menggunakan pembelajaran langsung. Hal tersebut dapat ditunjukkan dengan hasil perolehan nilai rata-rata setiap aspek, yaitu dengan model pembelajaran berbasis proyek perolehan nilai rata-rata 79,66, sedangkan perolehan nilai rata-rata dengan pembelajaran langsung 59,76. Hasil uji hipotesis menggunakan uji inferensial jenis uji-t independent sample test nilai t sebesar 14,293 dengan derajat kebebasan 68 dan p-value 
$(2$ tailed $)=0,000$. Karena nilai p-value $<0,05$ atau 0,000 $<0,05$ maka hipotesis nol $(\mathrm{H} 0)$ ditolak dan hipotesis alternatif (H1) diterima dan dapat disimpulkan jika model pembelajaran berbasis proyek efektif diterapkan dalam pembelajaran menulis teks eks posisi.

\section{DAFTAR PUSTAKA}

Alwasilah. (2005). Pokoknya Menulis. Bandung: Kiblat Buku Utama.

Badan Pengembangan Sumber Daya Manusia Pendidikan dan Kebudayaan dan Penjaminan Mutu Kebudayaan. (2013). "Model Pembelajaran Berbasis Proyek (Project Based Learning)", Bahan Presentasi. Kementrian Pendidikan dan Kebudayaan.

Finoza, L. (2001). Komposisi Bahasa Indonesia. Jakarta: Dwadasa Sarana Bersama.

Gie, T. L. (2002). Terampil Mengarang. Yogyakarta: Andi Offset.

Iskandarwassid \& Sunendar. (2008). Strategi Pembelajaran Bahasa. Bandung: Rosdakarya.

Kemendikbud. (2013). Kurikulum 2013, Standar Kompetensi Dasar Sekolah Menengah Atas (SMA)/Madrasah Aliyah. Jakarta.

Knapp, P., \& Megan, W. (2005). Genre, Text, Grammar, Sydney: University of New South Wales. Kompas. (2013). “Dana Kurikulum 2013 Dijanjikan Tepat Sasaran”, Kompas, 15 April 2013.

Mahsun. (2013). "Pembelajaran Bahasa Indonesia Menggunakan Pendekatan Teks", (Kompas Edu. 27 Februari 2013. Diakses pada tanggal 8 April 2013).

Rahaor, P. P. (2006). “Upaya Peningkatan Kemampuan Menulis Eksposisi melalu STAD dalam Pembelajaran Bahasa Indonesia Siswa Kelas V SDN Sumbersari II Malang", Tesis, Tidak diterbitkan, Malang: Program Pasca Sarjana Universitas Negeri Malang.

Tarigan, H. G. (2008). Menulis Sebagai Suatu Keterampilan Berbahasa. Bandung: Angkasa.

Wena, M. (2011). Strategi Pembelajaran Inovatif Kontemporer: suatu Tinjauan Konseptual Operasional. Jakarta: Bumi Aksara.

Zainurrahman. (2011). Menulis: dari Teori hingga Praktik (Penawar Racun Plagiarism). Bandung: Alfabeta. 